\title{
Ortaokul Beceri Temelli Soruların Yeniden Yapılandırılmış Bloom Taksonomisine Göre Değerlendirilmesi
}

\section{Münevver SANCA* ${ }^{*}$ Hüseyin ARTUN ${ }^{* *}$ Hasan BAKIRCI ${ }^{* * *}$ Murat OKUR ${ }^{* * * *}$}

Öz: Ülkemizin 2023 Eğitim Vizyonunda, ölçme değerlendirmede süreç ve sonuç odaklı bütünleşik bir anlayışın ortaya konulması, akademik başarının ölçülmesinde kullanılan ölçütler ile değerlendirme biçimlerinin çeşitlendirilmesi ve eğitim sistemimizdeki tüm sınavların; amac1, içeriği, soru tiplerine bağlı yapısı ve sağlayacağı yarar bağlamında yeniden düzenleneceği üzerine vurgu yapılmaktadır. Bu araştırmada da Millî Eğitim Bakanlığı [MEB] tarafindan ortaokul beşinci, altıncı ve yedinci sınıf öğrencileri için hazırlanan ve yayımlanan beceri temelli sorular revize edilmiş Bloom taksonomisinin bilişsel alan ve bilgi türleri boyutuna uygunluk bakımından incelenmiştir. Araştırmanın deseni nitel araştırma yaklaşımlarından biri olan doküman analizi olarak belirlenmiştir. MEB tarafından beşinci, altıncı ve yedinci sınıflar için hazırlanan beceri temelli 180 adet çoktan seçmeli soru örneklem grubuna seçilmiştir. Alanında üç uzmanın bu soruları Bloom' un taksonomisinde yer alan bilgi türleri ve bilişsel alan basamaklarına uygunluk bakımından karşılaştırması ile analiz edilmiştir. Çalışmanın sonucunda, beceri temelli soruların olgusal bilgi $(\% 21,6)$, işlemsel bilgi $(\% 3,8)$, kavramsal bilgi $(\% 74,6)$ basamağında olduğu görülmüştür. Bununla birlikte soruların hatırlama $(\% 14,4)$, anlama $(\% 77,9)$, uygulama $(\% 1,6)$, çözümleme $(\% 1,1)$, yaratma $(\% 5)$ basamağında olduğu saptanmıştır. Çoğunluk olarak değerlendirildiğinde beceri temelli soruların ezberden uzak, yaratıcı düşünmeyi sağlayabilen, problem çözme becerilerinin

\footnotetext{
*Fen Bilimleri Öğretmeni, Milli Eğitim Bakanlı̆̆1, Orcid No: 0000-0002-8460-1967, sancamunevver@gmail.com ${ }^{* *}$ Doç. Dr. Van Yüzüncü Yıl Üniversitesi, Temel Eğitim Bölümü, Orcid No: 0000-0002-8496-918X, Email: huseyinartun@gmail.com,

${ }^{* * *}$ Doç. Dr. Van Yüzüncü Yıl Üniversitesi, Temel Eğitim Bölümü, Orcid No: 0000-0002-7142-5271, Email: hasanbakirci09@gmail.com

Dr. Öğr. Üyesi, Cumhuriyet Üniversitesi, Temel Eğitim Bölümü, Orcid No: 0000-0003-2502-2276, Email: okurmurat55@hotmail.com.

${ }_{* * * * *} \mathrm{Bu}$ araştırma için Van Yüzüncü Yıl Üniversitesi Sosyal ve Beşeri Bilimleri Etik Kurulu Başkanlığında (13/05/2020) tarih ve 2020/03-04 sayısı) etik izin alınmıştır.
}

Gönderim: 03.07.2020 Kabul: 21.09.2020 Yayın:15.01.2021


kazanılmasını hedefleyen, hayal gücünü tetikleyen, günlük hayattaki problemleri içeren ve üst düzey zihinsel becerileri harekete geçirecek türden olması gerektiği de öneriler arasındadır.

Anahtar kelimeler: Beceri temelli soru, Revize edilmiş bloom taksonomisi, Fen eğitimi

\section{Evaluation of Secondary School Skill-Based Questions in Accordance with the Restructured Bloom Technology}

Abstract: In the 2023 Education Vision of our country, it is pointed out that an integrated process-oriented and result-oriented understanding in measurement and evaluation should be of high priority; that the evaluation methods and criteria used for the measurement of academic achievement should be varied; and that all the exams in our education system will be rearranged within the context of their goals, contents, question types and benefits. In the present study, the skill-based questions prepared and published by the Ministry of National Education [MoNE] for secondary school $5^{\text {th }}, 6^{\text {th }}$ and $7^{\text {th }}$ grade students were revised and examined with respect to their appropriateness to the dimension of cognitive domain and knowledge types of Bloom taxonomy. The study was conducted using the document analysis method, one of qualitative research approaches. In the study, a total of 180 skill-based multiple-choice questions prepared by MoNE for secondary school $5^{\text {th }}, 6^{\text {th }}$ and $7^{\text {th }}$ grade students constituted the research sample. The questions were analyzed by three field experts in terms of appropriateness to the steps of cognitive domain and knowledge types found in Bloom's taxonomy. The results revealed that all the skill-based questions included in the research sample belonged to the steps of phenomenological knowledge (21,6\%), procedural knowledge (3,8\%) and conceptual knowledge (74,6\%). In addition, the questions belonged to the step of remembering $(14,4 \%)$, understanding (77,9\%), application (1,6\%), analysis (1,1\%) and creation (5\%). When the skillbased questions were taken into account in general terms, it could be stated that they should avoid memorization, encourage critical thinking, aim to help acquire problem solving skills, trigger imagination, include daily life problems and activate upper-level mental skills.

Keywords: Skill-based question, Revised bloom taxonomy, Science education 


\section{Giriş}

Bilgi çağının büyük bir ilerleme yaşadığı şu günlerde eğitim sistemimizde amaç, bilgileri öğrencilere dayatmak değil onlara rehberlik ederek kendi deneyimleriyle bilgilere ulaşmalarını sağlamaktır. Aynı şekilde var olan bilgiyi alıp o bilgide hiçbir değişiklik yapmadan kullanan öğrencilerin yetiştirilmesi, çağımızın teknoloji ve bilim ihtiyaçlarına ters düşmektedir. Ayrıca bu biçimde yetişen öğrencilerin ülkelerini teknoloji ve bilim yarışında ileri seviyelere götüremeyeceği de söylenebilir. Bu bağlamda yenilikçi eğitim sistemlerinin önemi anlaşılmış ve eğitim sistemlerinde köklü değişiklikler kaçınılmaz bir hal almıştır. Bir öğrencinin kazanması gereken üst düzey zihinsel süreç becerilerinin önemi burada karşımıza çıkmaktadır. 2018 yılında yenilenen Fen Bilimleri Dersi Öğretim Programı yenilikçi ve modern bir eğitim anlayışını benimsemiş ve aynı zamanda üst düzey zihinsel süreç becerilerine ayrıca vurgu yapmıştır. $\mathrm{Bu}$ kapsamda çağın gerektirdiği bilgi, beceri ve anlayışa sahip, yaratıcı düşünebilen, öğrendiklerini kavrayabilen, eleştirel düşünebilen, sorgulayabilen, bilgiye ulaşmada bilimsel süreç becerilerini kullanabilen, bilgilerini zihninde yapılandıran, var olan bilgilerini sentezleyip yeni bilgiler ortaya koyabilen, edindiği bilgileri yeni durumlara aktarabilen, mantıklı bireyler yetiştirmek eğitim sistemlerinin temel hedeflerinden biri olmuştur (Tanık ve Saraçoğlu, 2011).

Temel bilimsel kavramlar ile bilgiler dâhilinde, istekli, meraklı, paylaşımcı olma gibi bilimsel davranışlar ve üst düzey düşünme becerilerinin kazandırılması fen eğitiminin hedefleri arasındadır (Çınar ve İlik, 2013). Fen Bilimleri Dersi Öğretim Programı incelendiğinde üst düzey zihinsel süreç becerilerinin öğrencilere kazandırılmasını hedefleyen yapılandırmacılık felsefesine göre hazırlanmış bir program olduğu görülmektedir (Demir ve Dindar, 2006). İlköğretim kademesi, üst düzey düşünme ve zihinsel süreç becerilerinin kazandırılması açısından önemlidir. Çünkü bu kademede öğrencilerin bilgi ve becerilerinin temelleri atılır. Bu bağlamda Fen Bilimleri dersinin önemi karşımıza çıkar. Fen Bilimleri dersi, çevremizi ve kendimizi tanıyıp anlamamız, yaşadığımız çağa ayak uydurmamız, yeni bilim insanları yetiştirmemiz, problem çözme becerilerimizi artırarak hayata olan uyumumuzun kolaylaşması açısından önem arz etmektedir (Çavuş, Balçın ve Yılmaz, 2018).

Fen Bilimlerinin temelinde bilimi anlama, olguları ve olayları doğru irdeleme, bilime ilgi duyma ve günlük hayattaki problemleri çözerken bilimsel süreç becerilerini kullanarak bir bilim insanı gibi davranmamız yatar. Fakat burada bilimsel süreç becerilerini ne derecede kullandığımızı test etmek için geçerli ve güvenilir olan ölçme aracına ihtiyaç vardır. Öğrencilerin zihinsel süreçlerini harekete geçirip, içinde bulundukları durumla ilgili gerekli 
sorgulamaları yapmaları için soru sormanın çok önemli bir beceri olduğu anlaşılmaktadır (Çalışkan, 2011). Aynı şekilde 2023 Eğitim Vizyonunda da ölçme ve değerlendirme etkinliklerinin öneminden bahsedilmiştir. Ölçme ve değerlendirmenin teknik bir konu olmasıyla birlikte nasıl bir nitelikte insan yetiştirmek istendiği de benimsenen eğitim felsefesi ve amaçlarıyla ilişkilidir. Neyin, nasıl ve hangi amaçla ölçüldüğü düşünülürse burada vereceğimiz her türlü cevap öğrencilerin bütün yönleriyle gelişimini ele almaktadır (MEB, 2018).

Öğretim işleminin kalitesi, öğretim işleminden sonra ölçme araçlarıyla ölçülmeli ve niteliği ortaya konulmalıdır. Bunun için çeşitli ölçme araçları kullanılmaktadır. Literatürde birçok ölçme değerlendirme tekniği mevcuttur. Bunlardan birisi de çoktan seçmeli sorulardır. Gündüz (2009)’ ün çalışmasında Fen Bilimleri dersi sorularının en fazla çoktan seçmeli türünde olduğunu tespit etmiştir. Çoktan seçmeli sorular genellikle dört veya beş seçenekten oluşan ve tek bir doğru cevabı olan sorulardır. Çoktan seçmeli sorular birçok eğitim kademesinde kullanılmaktadır. Nitelikli hazırlanırsa diğer ölçme araçlarına göre geçerlik ve güvenirliği en yüksek olan soru tipleridir. Kalabalık gruplarda uygulanabilir olması da bir diğer artısıdır. Bu tip sorular öğrencileri çoğu zaman düşünmeye yönlendirmektedir. Sonuç olarak öğrenmelerin kalıcılığı bu tip sorulardan oluşan sınavlarla test edilebilmektedir (Koray, Altunçekiç ve Yaman, 2005).

Öğretimi yapılan konuları bütün yönleriyle sorgulayabilen sorular, konuların öğrenciler tarafından ne seviyede öğrenildiğini ortaya koyabilmektedir. Burada önemli olan nokta, öğrencilerin bireysel farklılıklarına ve öğrenme düzeylerine hitap edebilecek soruların yazılmış olmasıdır. İyi hazırlanmış bir soru, bilgileri sadece hatırlamanın yanında bazı bilgilerin özümsenerek yeni ve farklı durumlara entegre edilmesini de içermelidir. Bu sayede üst düzey zihinsel yeteneklerin geliştirilmesi mümkün olabilir. Yazılmış bir sorunun amaca ne derecede hizmet ettiğinin tespit edilmesi için Bloom' un taksonomisi yeniden yapılandırılma yoluna gidilmiştir. Bloom ve arkadaşları tarafından 1956 yılında yayınlanan Bloom taksonomisi ilk defa “Taxonomy of Educational Objectives: Cognitive and Affective Domains” isimli eserde anlatılmıştır (Bloom, 1956). Bu eserde Bloom taksonomisinin basamakları "bilgi, kavrama, uygulama, analiz, sentez ve değerlendirme” olarak ele alınmıştır. Basitten karmaşığa doğru ilerleyen bu hiyerarşik düzende üst basamaklar, alt basamaklardan daha fazla bilişsel beceri içermektedir (Cumhur, Çavdar ve Polat, 2018). Bloom bu taksonomide öğrenme alanlarını bilişsel, duyuşsal ve psikomotor olmak üzere üç ana başlıkta toplamıştır. Bu sayede soruların daha ayrıntılı bir şekilde sınıflandırılmasına olanak sağlanmıştır. Bununla birlikte Bloom 
taksonomisinin bilişsel alan sınıflandırmasında amaçlar net ve gözlenebilir ifadelerle belirtildiği için eğitim bilimlerinde kullanılmıştır (Ayvacı ve Türkdoğan, 2009).

Bloom taksonomisi Krathwohl ve arkadaşları tarafindan yeniden düzenlemiştir (Anderson \& Krathwohl, 2001). Bloom taksonomisinde yapılan bu düzenleme sonucunda program geliştirme uzmanları, ölçme değerlendirme uzmanları ve eğitimciler arasında iş birliğinin artması hedeflenmiştir. 2001 yılında yapılan düzenlemeyle bilişsel alan iki başlık altında toplanmıştır. Bu başlıklar bilgi ve bilişsel süreç boyutlarıdır. Bilgi boyutunda; olgusal bilgi, kavramsal bilgi, işlemsel bilgi ve üst bilişsel bilgi bulunmaktadır. Bilgi boyutu daha çok kazanımların isimsel kısmını ifade etmektedir. Bir diğer boyut ise bilişsel süreç boyutunda ise; “hatırlama, anlama, uygulama, çözümleme, değerlendirme, yaratma (yeniden oluşturma)” basamakları yer almaktadır. Bu basamaklarda genel olarak birbirini izleyen zihinsel etkinlikleri içermektedir. Basamaklar incelendiğinde daha önceki taksonomide var olan bilgi basamağı yerine "hatırlama"; kavrama basamağı yerine "anlama"; sentez basamağ1 yerine "yeniden oluşturma" basamakları getirilmiştir (Bkz. Tablo 1). Yapılan bu düzenlemeyle bilişsel alan sınıflandırmasının daha gerçekçi ve işlevsel olduğu düşünülmektedir (Çepni, Ayvacı ve Keleş, 2001).

Tablo 1. Yeniden yapılandırılmış Bloom taksonomisinin bilişsel alanı ve bilgi boyutu alanı

\section{Bilişsel Süreç Boyutu}

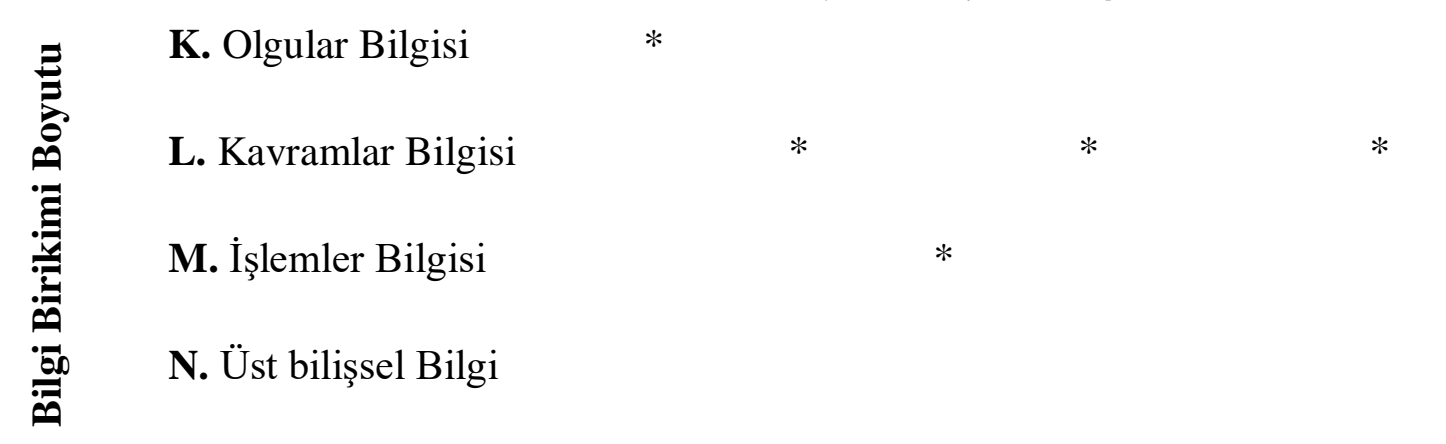

*Krathwohl (2002) 
Tablo 1'de incelendiğinde yeniden yapılandırılmış Bloom taksonomisinin orijinal taksonominin aksine iki boyutlu bir yapıya sahip olduğu söylenebilir. Yeniden yapılandırılan taksonominin bilgi boyutu incelendiğinde, orijinalinde de yer aldığg gibi olgusal, kavramsal ve işlemsel bilgi basamakları sabit kalmakla birlikte dördüncü alt basamak olarak üst bilişsel bilgi basamağı eklenmiştir. Bununla birlikte diğer üç alt basamak güncel gelişmeleri barındıracak biçimde yeniden düzenlenmiş ve alt kategorilere ayrılmıştır. Bilişsel alanın yeniden yapılandırılan bilgi boyutu ve bilgi boyutunun alt basamakları Tablo 2' te verilmiştir.

Tablo 2. Yeniden Yapılandırılmış Bloom Taksonomisinin Bilgi Birikimi Boyutu

\section{BİLGİ BOYUTUNUN TEMEL VE ALT TÜRLERİ}

\section{OLGUSAL BİLGí:}

Öğrencilerin bir konuyu tam olarak anlayabilmesi ve var olan problemlere kendince çözümler bulabilmesi için bilinmesi gereken temel ögeler

\section{A. Terimler bilgisi}

\section{B. Özel ayrıntı ve ögeler bilgisi}

\section{KAVRAMSAL BİLGİ:}

Bir yapıyı temsil eden ögeler arasındaki ilişkiler

\section{A. Sınıflamalar ve kategoriler bilgisi}

2.B. İlkeler ve genellemeler bilgisi

\section{C. Kavramlar, modeller ve yapılar bilgisi}

\section{3. İŞLEMSEL BİLGİ:}

Yapılmak istenen tasarım veya işlemlerin nasıl yapılacağı, araştırma yöntem ve teknikleri ve becerilerin kullanılacağı alanlar için ölçütler, işlemsel süreçler

\section{A. Konuya özgü beceri ve çözüm yollarının bilgisi}

3.B. Konuya özgü yöntem ve teknikler bilgisi

3.C. Uygun işlemlerin kullanılacağı zamanın belirlenmesine hizmet eden ölçütler bilgisi

\section{4.ÜST BİLISSSEL BİLGİ:}

Kişinin kendi bilişsel sürecinin farkındalığı, bilişle ilgili tüm bilgiler

\section{A. Stratejik/güdüsel bilgi}

4.B. Uygun bağlam ve koşulları kapsayan bilişsel görevler bilgisi

4.C. Öz-bilgi

*Krathwohl (2002) 
Yeniden yapılandırılan taksonominin bilgi boyutu incelendiğinde, basitten karmaşığa doğru ve bilişsel süreç boyutunun alt yapısını destekleyen nitelikte olduğu görülmektedir. Bu sayede bilgiyi sadece basitçe bir içerikle bağdaştırma yerine bilişsel süreçleri ortaya koymaya yardımcı olan bir bilgi birikimi şeklinde ele almayı sağlamıştır (Anderson, 2005). Örneğin; Tablo 2'de görüldüğü gibi bilgi boyutunda yer alan olgusal bilgi, bilişsel süreç boyutunda yer alan hatırlama alt basamağıyla, bilgi basamağında yer alan kavramsal bilgi ise yaratma ve anlama basamağıyla ilişkilendirilmiştir. Yine aynı şekilde bilgi boyutunda yer alan işlemsel bilgi, uygulama basamağıyla ilişkilendirilmiştir (Anderson, 2005; Baykul ve Turgut, 2010; Krathwohl, 2002). Başka bir dikkat çeken nokta ise yeniden yapılandırılan taksonomiyi orijinalinden ayıran en belirgin özelliğgi, bilgi birikimi boyutuna eklenen üst bilişsel bilgi basamağıdır. Üst bilişsel bilgi, orijinal taksonominin geliştirildiği dönemde fazla bilinen bir tanım değildir (Krathwohl, 2002). Ancak özellikle yapılandırmacı yaklaşımla birlikte oluşan kavramsal çerçevede üst bilişsel bilgi önemli bir yer kaplamaya başlamıştır. Yeniden yapılandırılan taksonomiye eklenen üst bilişsel bilgi, bireyin bilişi hakkındaki farkındalık düzeyi olarak tanımlanmış ve (A) stratejik/güdüsel bilgi, (B) bilişsel görevler bilgisi ve (C) özbilgi gibi alt basamakları içerecek bir şekilde yapılandırılmıştır. Uygun bağlam ve koşulları kapsayan bilişsel görevler bilgisi ise öğrenmenin sosyo/kültürel boyutu ile ilişkilidir ve bilginin kültüre özgü yönünü yansıtarak, öğrenmeyi açıklamada sosyal öğrenme kuramına vurgu yapar. Son basamakta yer alan öz-bilgi ise farklı strateji ve bilişsel görevlerle ilgili bilginin yanı sıra kişinin güçlü ve zayıf yönlerine ilişkin bilgisi olarak tanımlanmaktadır. Yeniden yapılandırılmış Bloom taksonomisinin bilişsel süreç boyutu ise Tablo 3' te gösterildiği gibi sınıflandırılmıştır. Ayrıca Bloom taksonomisinin bilişsel boyutu temel olarak 6 ana ve 19 alt başlıktan oluşmuştur.

Tablo 3. Yeniden Yapılandırılmış Bloom Taksonomisinin Bilişsel Süreç Boyutu

1.Hatırlama: Uzun süreli bellekte var olan bilgileri geri alma

\section{A. Tanıma}

\section{B. Anımsama}

2.Anlama: Öğretimsel birtakım mesajlardan sözel ya da sayısal bilgilerden anlamlı bütünler oluşturma

\section{A. Yorumlama}

\section{B. Örnekleme}

\section{C. Sinıflandirma}




\section{D. Özetleme}

\section{E. Sonuç çıkarma}

2.F. Karşılaştırma

\section{G. Açıklama}

3.Uygulama: Verilen bir durumda uygun işlemi kullanma ya da uygulama

\section{A. Yürütme}

\section{B. Yapma}

4.Çözümleme: Bir materyali bileşenlerine ayırma, bileşenlerin birbirleriyle ve genel yapıyla nasıl örtüştüğünü keşfetme

\section{A. Ayriştırma}

\section{B. Örgütleme}

4.C. İrdeleme

5.Değerlendirme: Ölçütlere dayanarak birtakım yargılara varma

\section{A. Denetleme}

\section{B. Eleştirme}

6.Yaratma: Özgün bir ürün ortaya koyabilmek için öğeleri tutarlı ya da işlevsel olabilecek şekilde bir araya getirme

\section{A. Oluşturma}

\section{B. Planlama \\ 6.C. Üretme}

*Krathwohl (2002)

Literatürde yeniden yapılandırılmış taksonomiye göre yapılan sınavların sorularının değerlendirildiği çalışmalar mevcuttur. Mandac1-Şahin (2007) çalışmasında, öğretimde yapılandırmacı bir yaklaşımı benimsemiş bir ülke olmamıza rağmen yapılan ulusal ve uluslararası sınavlar incelendiğinde ölçme ve değerlendirme anlamında bu yaklaşımı çok da benimseyemediğimizi ifade etmiştir. Burada öğrenci merkezli eğitim anlayışının tam olarak benimsenememiş olduğu çıkarımı yapılabilir ve bu açığı kapatmak için çoktan seçmeli soruların yapılandırmacı yaklaşıma göre oluşturulmasına dikkat edilmesi gerektiği vurgulanmalıdır. Ölçme aracı olarak kullanılan çoktan seçmeli sorular hazırlamak her bireyin yapabileceği bir eylem olmamalıdır. Soru yazabilmek için bireyleri meraklandırmayı bilmek, öğrenme için bireyleri istekli hale getirebilmek, bilgileri sınamaya dayalı çeşitli ifadeler ortaya koymak gereklidir (Akbulut, 1999). Köğce ve Baki (2009a) çalışmalarında ise matematik öğretmenlerinin hazırladıkları sınav soruları incelenmiş ve soruların genel olarak alt düzey 
düşünme becerilerini ölçtüğü sonucuna varılmıştır. Gündüz (2009)' un çalışmasında Fen ve Teknoloji soruları incelenmiş ve bu soruların \%64.65'inin bilgi düzeyinde olmakla birlikte \%92,19'unun alt düzey sorular olduğu sonucuna ulaşılmıştır. Bununla birlikte Ayvacı ve Türkdoğan (2010) yaptıkları çalışmada öğretmenlerin Fen ve Teknoloji dersinde hazırladıkları yazılı sorularını yeni taksonomiye göre incelemişler ve soruların \%55 oranında hatırlama ve bilme seviyesinde olduğu sonucuna ulaşmışlardır. Bir diğer çalışmada ise 2013 Fen Bilimleri öğretim programında bulunan kazanımlar yenilenmiş Bloom taksonomisine göre incelenmiş ve kazanımların yaklaşık \% 69 oranında taksonominin alt bilişsel düzey basamaklarında bulunmakla birlikte bilgi boyutu bakımından incelendiğinde ise \%63 oranında kavramsal bilgi boyutunda yer aldığı sonucuna ulaşılmıştır (Yaz ve Kurnaz, 2013). Karaman ve Bindak (2017) çalışmalarında TEOG sınav sorularının \%72,5'inin alt düzey ve \% 27,5'inin üst düzey; öğretmenlerin hazırladıkları sınav sorularının \% 41,3 anlama ve uygulama basamağında olduğunu tespit etmişlerdir. Güven ve Aydın (2017)' in çalışmalarında ise 8. sınıf fen bilimleri dersi öğretim programında yer alan soruları incelediğinde ise soruların \%48,72'sinin anlama basamağında olduğu sonucunu ortaya koymuştur. 2017 y1lı Fen Bilimleri taslak programında yer alan kazanımların yenilenmiş Bloom taksonomisine göre incelendiği bir çalışmada kazanımların \%8,65'inin hatırlama, \% 40,79'unun anlama , \% 16,35'inin uygulama, \% 11,65'inin analiz, \% 3,95'inin değerlendirme ve \% 16,92'sinin yaratma basamağında olduğu tespit edilmiştir (Cangüven, Öz, Binzet ve Avc1, 2017). Yolcu (2019) 3. ve 4. sınıf Fen Bilimleri öğretim programında yer alan kazanımları revize edilmiş taksonomiye göre değerlendirdiğinde ise \%43 oranında anlama basamağına hitap ettiği sonucuna ulaşmıştır.

Genel olarak yapılan çalışmalarda alt düzey zihinsel becerileri ölçen, bilgiyi sadece sorgulayan ve ezbere dayalı olan sorular yerine; bilgileri yorumlatabilen, var olan bilgileri yeni durumlara uyarlatabilen ve farklı disiplinlerle ilişki kurma olanağı sağlayabilen soruların hazırlanması gerektiğine vurgu yapmışlardır. Görüldüğü gibi yeniden yapılandırılmış Bloom taksonomisi, literatürde sıkça yer verilen bir konudur. Fakat bu konuda gerek Fen Bilimleri dersi gerekse de Fen Bilimleri dersi öğretim programıyla ilgili yapılan çalışmalar sınırlı sayıdadır. Ayrıca incelenen çalışmalara bakıldığında yıllar ilerledikçe bilim ve teknolojinin gelişmesiyle öğrencilere yöneltilen soruların ait olduğu basamakların genel olarak birbiriyle paralel olduğu yani alt düzey zihinsel becerilere hitap ettiği saptanmıştır. Günümüzde bu eksiği kapatma adına MEB tarafından Beceri Temelli Testler yayımlanmış ve bu soruların öğrencilere mutlaka çözdürülmesi gerektiği uyarıları yapılmıştır. Buradan yola çıkarak üzerinde uzun zaman durulan ve bütün paydaşlar tarafından dikkate alınan Beceri Temelli olarak adlandırılan 
soruların hangi zihinsel sürece hitap ettiğini ortaya çıkarmak için bu çalışma ortaya konmuştur. Ayrıca bu çalışma, üst düzey düşünme becerilerinin önemi ve öne çıkarılması gerektiği konusunda bir farkındalık yaratmak için ortaya konmuştur.

\section{Yöntem}

\section{Araştırmanın Deseni}

$\mathrm{Bu}$ araştırmada nitel araştırma yöntemlerinden biri olan doküman incelemesi yöntemi kullanılmıştır. Doküman incelemesi, araştırılacak olan olgu veya olaylar hakkında bilgi içeren görsel materyallerin incelenmesidir (Yıldırım ve Şimşek, 2018, s.189). Bir başka deyişle doküman analizi, yapılacak olan araştırmayla ilgili var olan yazılı materyalleri toplayıp belirli bir sistem dâhilinde gruplandırıp inceleme işlemidir (Çepni, 2018, s.118). Ayrıca doküman incelemesi doğrudan görüşme ya da gözlemin mümkün olmadığ 1 durumlarda veya herhangi bir nitel araştırma deseninin tamamlayıcısı olarak kullanılabilmektedir (Bowen, 2009).

\section{Veri Kaynağı}

Araştırma verilerini 7 Ekim 2019 tarihinde MEB resmî sitesinde yayımlanan Fen Bilimleri dersine yönelik beceri temelli çoktan seçmeli sorulardan oluşan testler oluşturmaktadır. Söz konusu beceri temelli sorular, MEB tarafından sadece 5., 6., 7. sınıf kademesinde ve her kademenin ilk üç ünitesini kapsayacak şekilde yayımlandığ 1 için araştırmanın verileri bu kapsamda şekillenmiştir.

\section{Verilerin Elde Edilmesi}

Çalışmanın amacı ve ana problemleri saptandıktan sonra MEB resmî sitesinden alınan beceri temelli sorular her kademe bazında üç grup halinde yazılı materyal haline getirilmiştir. Ayrıca araştırmanın temel noktasını oluşturan Bloom taksonomisi de alan yazın ışı̆̆ında oluşturulup tablolar haline getirilmiştir.

\section{Verilerin Analizi}

Araştırmanın ana problemi dikkat alınarak veriler analiz edilmiştir. Soruların analizi yapılırken yeniden yapılandırılmış Bloom Taksonomisinin bilişsel süreç ve bilgi birikimi boyutları dikkate alınmıştır. Soruların taksonomideki hangi basamağa ait olduğunu bulmak için öncelikle soruların ana ifadeleri olan cümle yapılarına odaklanılmıştır. Bir cümle isim ve fiil kelimelerinin bir araya gelmesiyle oluşmaktadır. Soru analizinde sorular ad ve fiil olarak iki kısma ayrılmış ve daha sonra sorunun ad kısmı bilgi boyutunun bulunmasını sağlarken fiil kısmı bilişsel süreç boyutunun ne olduğunun bulunmasını sağlamıştır. Bu analizde yatay ve 
dikey boyutlardan oluşan taksonomi tablosuna soruları yerleştirirken taksonomi tablosunda yer alan fiiller ve isimler göz önüne alınarak karar verilmiştir (Tablo 2 ve Tablo 3).

Çalışmada kuramsal geçerliği oluşturmak adına soruların ne şekilde sınıflandırıldığını açıklamak için analiz edilen soruların bilişsel seviyelerinin ve bilgi türlerinin belirlenmesine ilişkin aşağıdaki soru örnekleri paylaşılmıştır.

"Hatırlama” ve “Olgusal Bilgi” basamağına örnek bir soru:

4. Aşağıdaki görselde Ay'da yürüyen astronotların oluşturduğu izler görülmektedir.

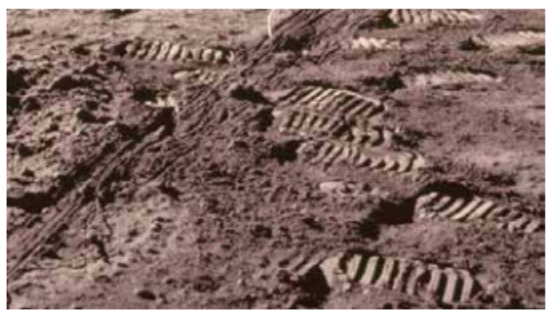

Uzun yıllar geçmesine rağmen oluşan bu izlerin bozulmadan kalması Ay'ın hangi özelliğinden kaynaklanmaktadır?
A) Yüzeyinin tozla kaplı olması
B) Kendi ekseni etrafında dönmesi
C) Küresel bir şekle sahip olması
D) Atmosferinin yok denecek kadar az olması

Örnek olarak verilen soru, Ay’ın özellikleriyle ilgili uzun süreli bellekte var olan bilgileri geri alınmasını istediği için Bloom Taksonomisinin bilişsel alan basamaklarından "hatırlama” basamağındadır. Ayrıca örnekte verilen soru Bloom Taksonomisinin bilgi türleri basamakları bakımından incelendiğinde, Ay ile ilgili temel özellikleri meydana getiren bilgileri kullanmayı gerekli kıldığı için "olgusal bilgi” basamağındadır.

“Anlama” ve “Kavramsal Bilgi” basamağına örnek bir soru:

\section{GÜNES}

Güneş, evrendeki yüz milyarlarca yıldızdan biridir ve Güneş'in etrafında dolanma hareket yapan Dünya'ya yaklaşık 150 milyon kilometre uzaklıktadır. Bu sebeple Dünya'dan bakıldığında olduğundan küçük görünür. Güneş'in merkezinde çok sıcak ve çok yoğun olan çekirdek bulunur. Güneş'in gözümüzle gördüğümüz katmanı ışık küredir. Işık kürenin üzerinde de renk küre ve taç küre adlı iki katman bulunur.

Așağıda bulunan görsellerden hangisinin açıklaması Güneş ile ilgili verilen metinde yer almaz?
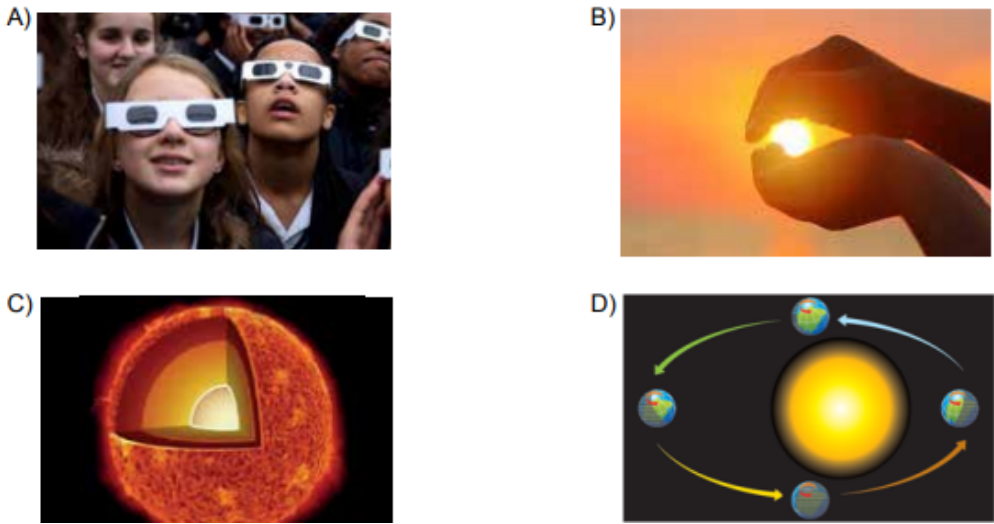
Örnek olarak verilen soru, öğrencilerden Güneş’in özelliklerinin verilen görselden yola çıkılarak ve görselde yazanlar yorumlanarak açıklanmasını istediği için "anlama" basamağındadır. Ayrıca verilen soru, görseldeki Güneş ile ilgili bilgilerin kategorize edilmesini sağladığı için "kavramsal bilgi”" basamağındadır.

"Uygulama” basamağına örnek bir soru:

Güneş, Dünya ve Ay’ın hareketleri ile ilgili aşağıdaki bilgiler verilmiştir:

- Güneş kendi etrafında döner.

- Dünya kendi etrafında dönerken Güneş etrafında dolanma hareketi yapar.

- Ay kendi etrafında dönme hareketi yaparken Dünya etrafında dolanma hareketi yapar.

Verilen bilgilere göre Güneş, Dünya ve Ay'ın birbirlerine göre hareketlerini gösteren modellerden hangisi doğru çizilmiştir?

A)

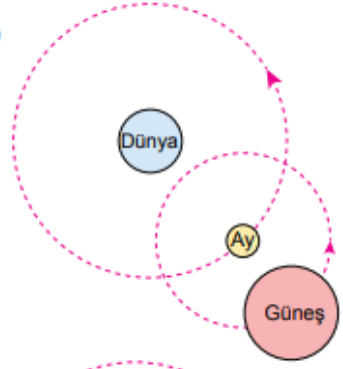

C)

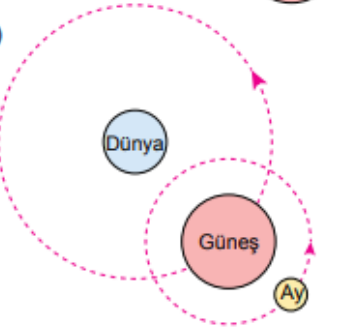

B)

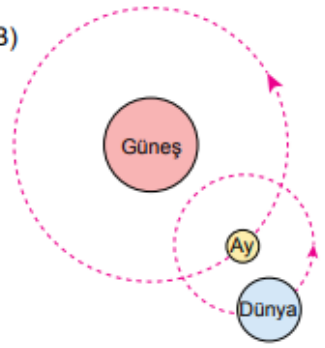

D)

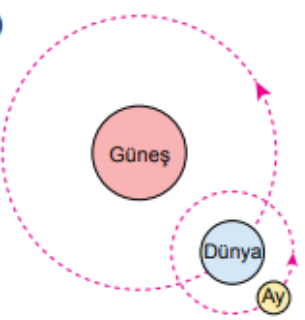

Örnek olarak verilen soru, Güneş'in, Dünya'nın ve Ay’ın bazı hareketleriyle ilgili öğrencilerden model çizmelerini istediği için "uygulama" basamağındadır.

“Çözümleme” ve “işlemsel Bilgi” basamağına örnek bir soru: 


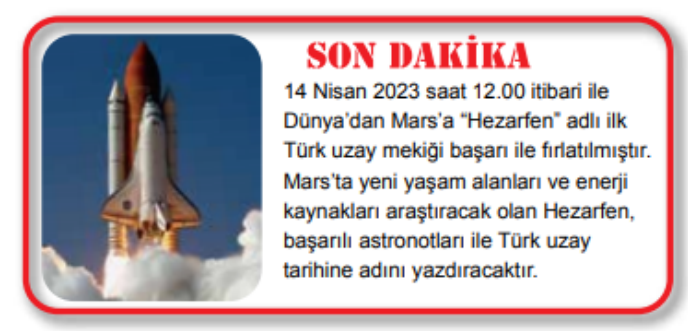

Dünya'dan yola çıkarak Mars'a iniş yapacak uzay mekiğine etki edecek çekim kuvvetinin zamana bağlı değişim grafiği aşağıdakilerden hangisi olabilir?

A)

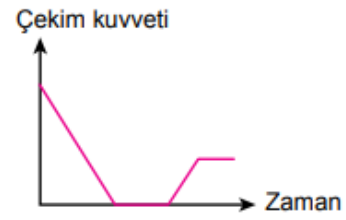

C)

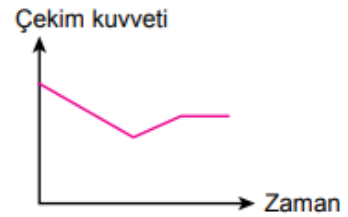

B) Cekim kuvveti

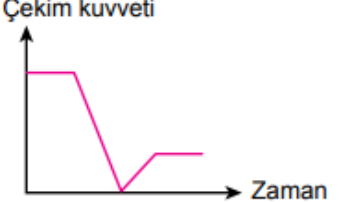

D) Çekim kuvveti

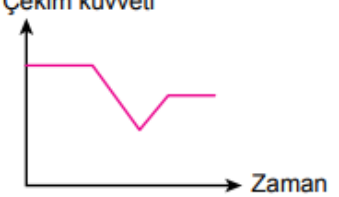

Örnek olarak verilen soru, görselde verilen paragrafin analiz edilerek bazı sonuçların çıkarılmasını sağladığı için "çözümleme" basamağındadır. Ayrıca bu soru mevcut bilgilerden yararlanarak yeni bir bilgi (grafik) üretmeyi sağladığ 1 için "işlemsel bilgi" basamağındadır.

"Değerlendirme" basamağına ait bir soru: 
ÜÇLŨ SET OYUNU

Mehmet ve Demet üzerinde mayoz ve mitoz bơlunmenin özelliklerinin yazılı olduğu pulları eșit olarak paylaşıp așağıdaki oyunu oynamaktadırlar. Oyunun amacı şekilde gösterilen ömeklerde olduğu gibi aynı böıunme çeșidine ait özel-

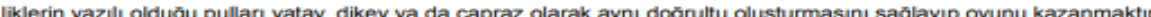
Așağıda oyunun belli bir anındaki durumu gösterilmiștir.

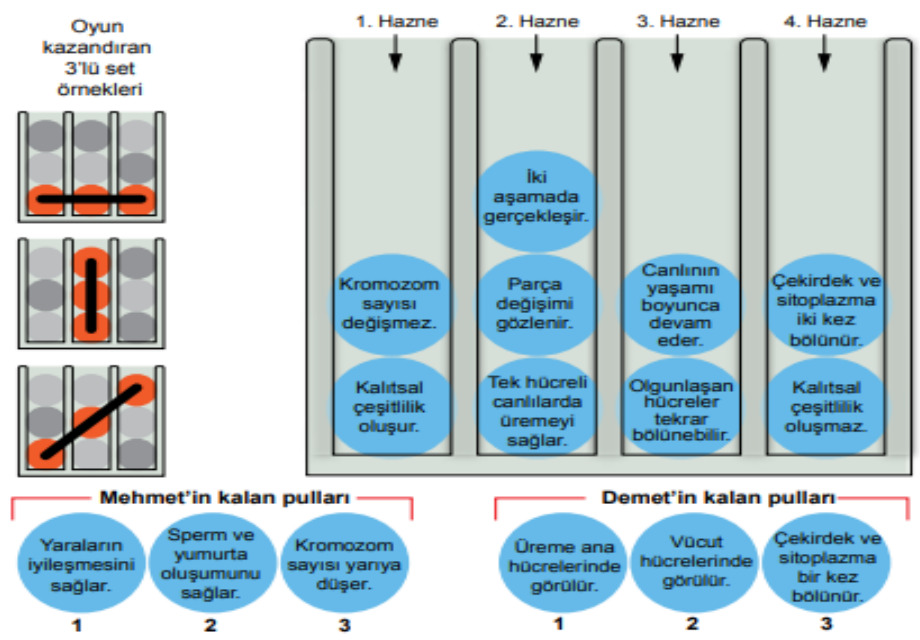

Buna göre hamle sırası gelen oyuncuyla ilgili aşağıdaki ifadelerden hangisi kesinlikle doğrudur?

A) Mehmet kalan herhangi bir pulunu 1. hazneye bıraktığı zaman oyunu kazanır.

B) Demet kalan herhangi bir pulunu 2. hazneye bıraktığında oyunu kazanır.

C) Mehmet kalan herhangi bir pulunu 3. hazneye bıraktı̆ı zaman oyunu kazanı

D) Demet kalan herhangi bir pulunu 4. hazneye bıraktığında oyunu kazanır.

Örnekte verilen soru, verilen ölçütleri değerlendirerek, mayoz ile mitoz bölünmeyle ilgili çeşitli bilgileri görseldeki oyunla birleştirerek gerekçelerle birlikte ifade edilmesini sağladığg için “değerlendirme” basamağındadır.

Araştırmacının ilk yaptığı analizlerin yanında iki öğretim üyesinin, bir ölçme değerlendirme uzmanının görüşleri alınarak analiz yapılması sağlanmıştır. $\mathrm{Bu}$ sorular araştırmacı tarafından Bloom' un bilişsel alan taksonomisine göre Tablo.1, Tablo.2 ve Tablo 3. dikkate alınarak sınıflandırılmıştır. Aynı veriler bir uzmanın da görüşleri alınarak soruların frekans ve yüzdeleri hesaplanmıştır. Daha sonra uzman ve araştırmacı bir araya gelerek ortaya çıkan sonuçlar karşılaştırılmıştır. Uyuşmazlıklar gözden geçirilmiş ve uzman eşliğinde ortak bir sonuca ulaşılmıştır. Bu işlemler bütün sorular tarafından birkaç kez tekrarlandıktan sonra araştırmacı soruların analizini yapmıştır. Böylece beceri temelli soruların Bloom' un bilişsel alan taksonomisine göre analizi yapılmış ve elde edilen sonuçlara göre hangi seviyede yazıldığı taksonominin iki boyutu ele alınarak irdelenmiştir.

\section{Geçerlik ve Güvenirlik Çalışmaları}

Nitel çalışmalarda, çalışmanın inandırıcı olması için geçerlik ve güvenilirlik çalışmalarına dikkat edilmelidir. Bunun için araştırmacının elde ettiği verileri detaylı bir şekilde raporlandırması ve bu verilerin sonuçlarına nasıl ulaştığını açıklaması için iç ve dış geçerlilik kuralına uymalıdır. İç geçerlik, araştırmacının veri toplama süreçlerinde ve verilerin 
analiziyle yorumlanması konusunda tutarlı olmasına bağlıdır. Bir başka deyişle iç geçerlik, araştırmacıların gözlemledikleri olaylar ya da anladıklarını düşündükleri olgularla ilgili yorumların gerçek durumu yansıtıp yansıtmamalarıyla ilgilidir (Ylldırım ve Şimşek, 2018). Bu çalışmada elde edilen bulguların benzer araştırmaları destekler nitelikte olduğu tespit edilmiştir. Ayrıca araştırmanın bulguları değerlendirilerek yapılan tahminlerin elde edilen verilerle yeteri kadar uyumlu olduğu görülmüştür. Bu sebeple araştırmanın iç geçerliği belirli oranda sağlanmıştır. Dış geçerlik, araştırma sonuçlarının benzer ortamlara ve durumlara genellenebilir olmasıyla ilişskilidir (Yıldırım ve Şimşek, 2018). Çalışmada dış geçerliği sağlayabilmek için benzer araştırmalar incelenmiş ve sonuçların birbirini destekler nitelikte olduğu görülmüştür. Bu durumda araştırmanın sonuçlarının benzer ortamlara ve durumlara belirli oranda genellenebildiği için araştırmanın dış geçerliğinin sağlandığı söylenebilir.

Güvenilirlik, birden fazla araştırmacının analiz sonuçlarının aynı olması, yapılan işlemlerin detaylandırılarak ortaya koyulması ve verilerin yorumlanmadan ham haliyle verilmesidir. İç güvenilirlik aynı alandaki araştırmacıların benzer verilerle benzer sonuçlara ulaşmasındaki tutarlılığı ifade eder. Dış güvenilirlik ise çalışmada ulaşılan sonuçların, benzer ortam koşullarında benzer sonuçlara ulaşılmasıdır (Başkale, 2016; Yıldırım ve Şimşek, 2018).

$\mathrm{Bu}$ araştırmada Bloom (1956) tarafından ortaya atılan bilişsel alan boyutlarını inceleyen taksonominin, Krathwohl (2002) tarafından yeniden yapılandırılmış hali kullanılmıştır. Araştırmacıyla aynı değerlendirmeye sahip cevaplar görüş birliği, farklı değerlendirmeye sahip cevaplar ise görüş ayrılığı olarak kabul edilmiştir. Her bir soru üzerinde araştırmacıya destek veren bütün uzmanların ayrı ayrı görüşleri alınmıştır. Araştırmanın güvenirliği; Güvenirlik=Görüş birliği/(Görüş birliği + Görüş ayr1lı̆̆1)*100 matematiksel ifadesi kullanılarak hesaplanmıştır. Buna göre araştırmanın güvenirliği \% 83,33 bulunmuştur. Sonucun 0,70 değerinin üzerinde bulunması araştırmanın güvenirliğini sağlamaktadır (Miles ve Huberman, 1994). Bundan dolayı yapılan sınıflandırma güvenilir olarak ifade edilebilir.

\section{Bulgular}

Araştırmanın amacı doğrultusunda MEB tarafından yayımlanan Fen Bilimleri dersi kapsamında 5, 6 ve 7. sınıflara yönelik beceri temelli 180 adet çoktan seçmeli soru yeniden yapılandırılmış Bloom taksonomisine göre iki farklı boyutta analiz edilmiştir. Her sınıf ve ünite bakımından aşağıda yer alan tablolar kullanılarak sunulmuştur. Tablo 4' de beşinci sınıf beceri temelli testlerinin Bloom taksonomisine göre değerlendirmesi verilmiştir. 
Tablo 4. Beşinci sınıf beceri temelli testlerinin Bloom taksonomisine göre değerlendirilmesi

\section{Bilişsel Süreç Boyutu}

\begin{tabular}{|c|c|c|c|c|c|c|c|}
\hline 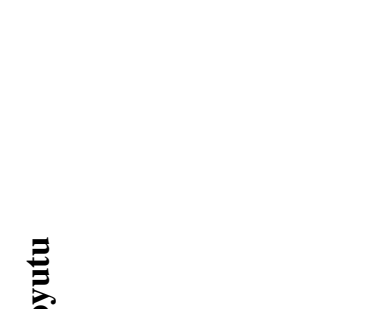 & 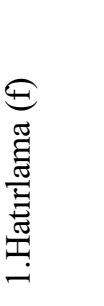 & 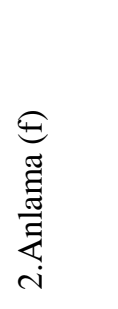 & 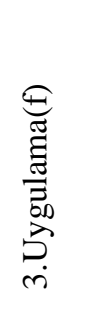 & 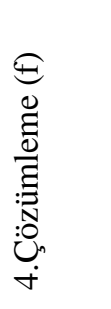 & 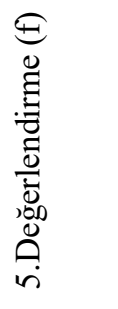 & 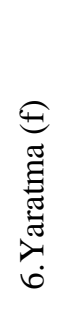 & 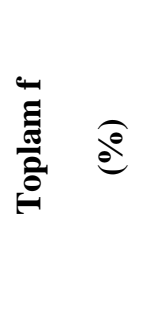 \\
\hline $\begin{array}{l}\text { K.Olgular } \\
\text { Bilgisi }\end{array}$ & 4 & 1 & - & - & - & 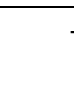 & $5(8,33)$ \\
\hline $\begin{array}{l}\text { L.Kavramlar } \\
\text { Bilgisi }\end{array}$ & 5 & 45 & 1 & 1 & 1 & . & $53(88,33)$ \\
\hline $\begin{array}{l}\text { M.İșlemler } \\
\text { Bilgisi }\end{array}$ & - & - & 2 & - & - & 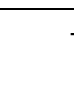 & $2(3,33)$ \\
\hline $\begin{array}{l}\text { N.Üst bilişsel } \\
\text { Bilgi }\end{array}$ & - & - & - & - & - & . & - \\
\hline Toplam f & 9 & 46 & 3 & 1 & 1 & . & \\
\hline (\%) & (15) & $(76,6)$ & (5) & $(1,7)$ & $(1,7)$ & & \\
\hline
\end{tabular}

*f: soru saylsl

Tablo 4 incelendiğinde taksonominin bilişsel süreç boyutu bakımından beşinci sınıf seviyesindeki beceri temelli 60 test sorusunun; \%76,6'sinın ( $f=46)$ anlama, \%15' unun (f=9) hatırlama, \%5' inin $(\mathrm{f}=3)$ uygulama, \%1,7' $\operatorname{sinin}(\mathrm{f}=1)$ çözümleme ve değerlendirme basamağında bulunduğu görülmektedir. Bununla birlikte beşinci sınıf seviyesindeki beceri temelli sorular taksonominin bilgi birikimi boyutu bakımından; \%88,33' ünün ( $\mathrm{f}=53$ ) kavramlar bilgisi, \%8,33’ ünün ( $\mathrm{f}=5$ ) olgular bilgisi ve \%3,33’ ünün $(\mathrm{f}=2)$ işlemler bilgisi ve \%0'ının ( $\mathrm{f}=0$ ) üst bilişsel bilgi basamağında olduğu görülmektedir. Tablo 5' te beşinci sınıf beceri temelli testlerinin Bloom taksonomisine göre değerlendirme tablosu verilmiştir. 
Tablo 5. Altıncı sınıf beceri temelli testlerinin Bloom taksonomisine değerlendirilmesi

\section{Bilişsel Süreç Boyutu}

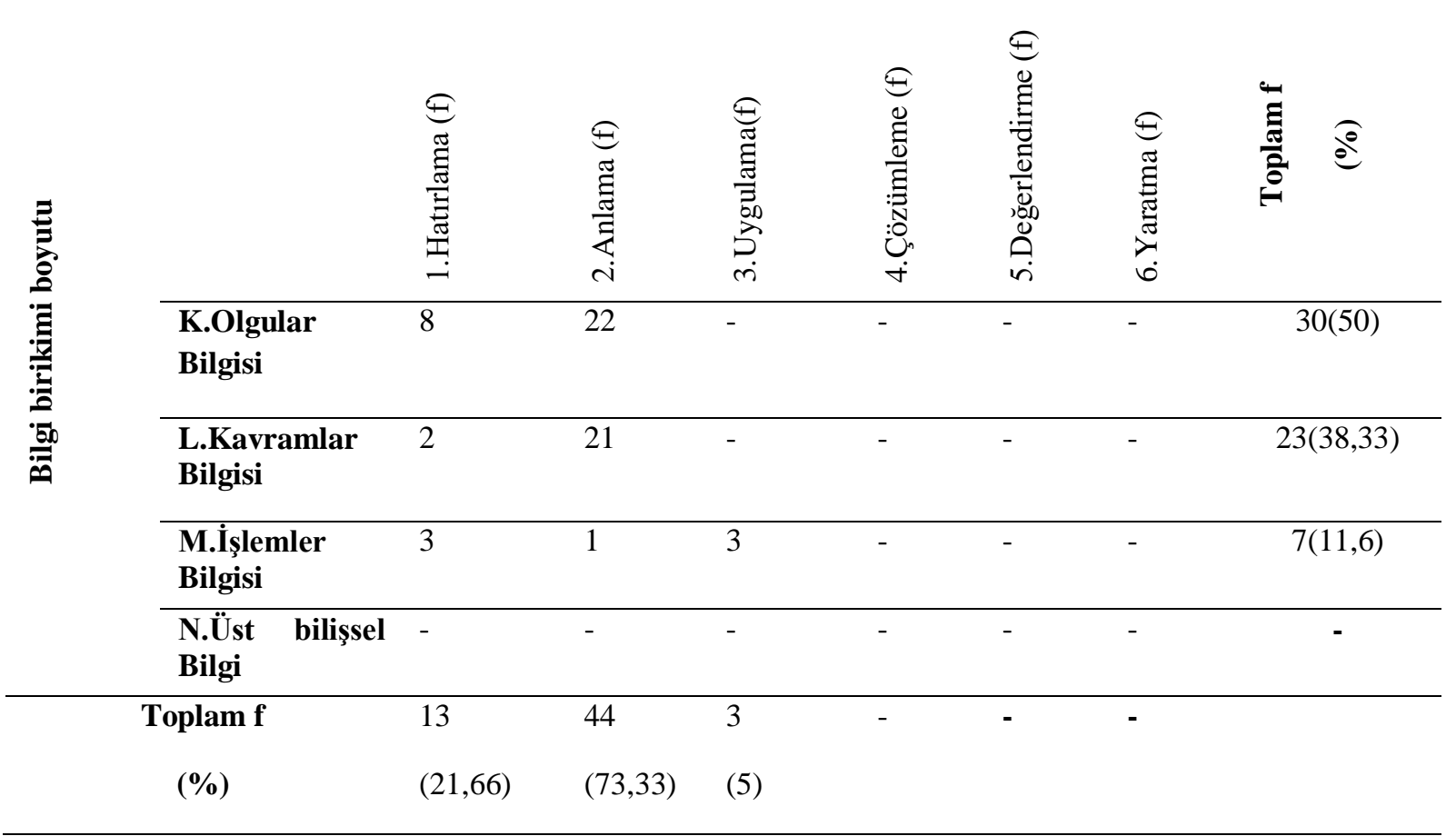

*f: soru saylsl

Tablo 5 incelendiğinde taksonominin bilişsel süreç boyutu bakımından altıncı sınıf seviyesindeki beceri temelli test sorularının; \%73,33' ünün ( $\mathrm{f}=44)$ anlama, \%21,66'sının (f=13) hatırlama ve \%5'inin ( $\mathrm{f}=3$ ) uygulama basamağında bulunduğu tespit edilmiştir. Aynı zamanda söz konusu sorular Bloom taksonomisinin bilgi birikimi boyutuna göre \%50’ sinin ( $\mathrm{f}=30$ ) olgusal bilgi, \%38,33’ünün ( $\mathrm{f}=23$ ) kavramsal bilgi ve \%11,66'sının ( $\mathrm{f}=7$ ) işlemler bilgisi ve \%0' $\operatorname{lnın}(\mathrm{f}=0)$ üst bilişsel bilgi basamağında olduğunu söylemek mümkündür. Tablo 6' da yedinci sınıf beceri temelli testlerinin Bloom taksonomisine göre değerlendirme tablosu verilmiştir.

Tablo 6. Yedinci sınıf beceri temelli testlerinin Bloom taksonomisine göre değerlendirilmesi

\section{Bilişsel Süreç Boyutu}

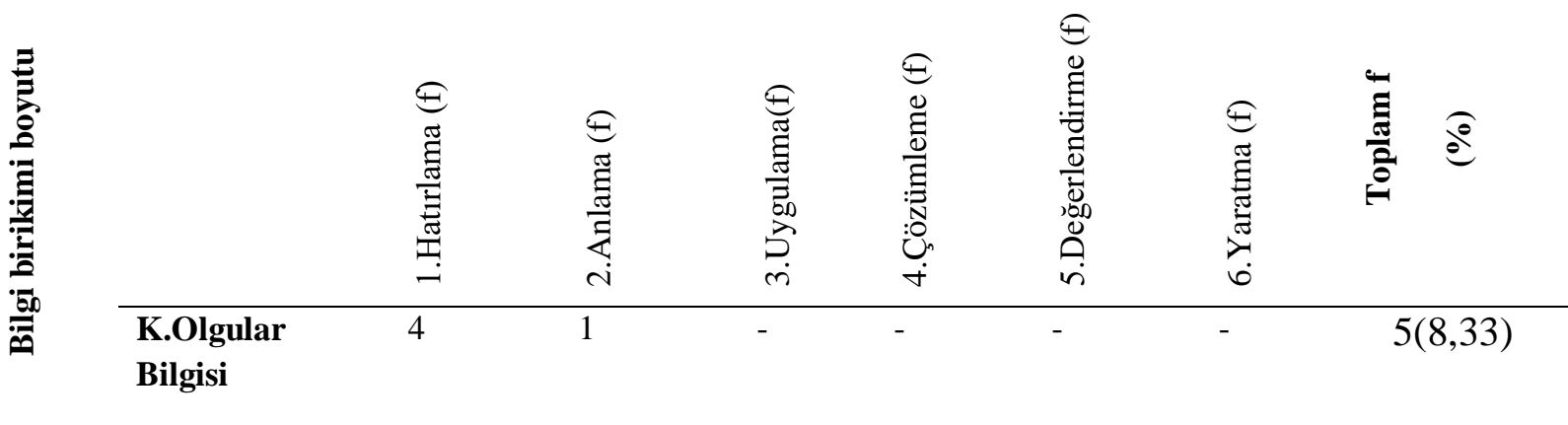




\begin{tabular}{|c|c|c|c|c|c|c|c|}
\hline $\begin{array}{l}\text { L.Kavramlar } \\
\text { Bilgisi }\end{array}$ & 5 & 45 & 1 & 1 & 1 & - & $53(88,33)$ \\
\hline $\begin{array}{l}\text { M.İşlemler } \\
\text { Bilgisi }\end{array}$ & - & - & 2 & - & - & - & $2(3,33)$ \\
\hline $\begin{array}{l}\text { N.Üst bilişsel } \\
\text { Bilgi }\end{array}$ & - & - & - & - & - & - & - \\
\hline Toplam f & 9 & 46 & 3 & 1 & 1 & - & - \\
\hline (\%) & (15) & $(76,6)$ & (5) & $(1,7)$ & $(1,7)$ & - & \\
\hline
\end{tabular}

*f: soru saylsl

Tablo 6 incelendiğinde Bloom taksonominin bilişsel süreç boyutu bakımından yedinci sınıf seviyesindeki beceri temelli test sorularının; \%76,6'sının ( $\mathrm{f}=46$ ) anlama, \%15'inin(f=9) hatırlama ve \%5'inin (f=3) uygulama, \%1,7’sinin (n=1) değerlendirme ile çözümleme ve \%0’ ının ( $\mathrm{f}=0$ ) yaratma basamağında bulunduğu tespit edilmiştir. Aynı zamanda söz konusu sorular Bloom taksonomisinin bilgi birikimi boyutuna göre \%88,33’ünün ( $f=53$ ) kavramsal bilgi, $\% 8$,33’ünün ( $\mathrm{f}=5$ ) olgusal bilgi ve $\% 3,33$ ’ ünün $(\mathrm{f}=2)$ işlemsel bilgi ve $\% 0$ ’ $\operatorname{lnın}(\mathrm{f}=0)$ üst bilişsel bilgi basamağında olduğu görülmektedir.

\section{Tartışma ve Sonuç}

Bu araştırmada MEB tarafından Fen Bilimleri dersi bünyesinde 5., 6. ve 7. sınıflar için ilk üç üniteyi kapsayan beceri temelli testler başlığı altında yayımlanan 180 adet soru, yeniden yapılandırılmış Bloom taksonomisinin iki farklı boyutu göze alınarak analiz edilmiştir. $\mathrm{Bu}$ analizler doğrultusunda elde edilen bulgulara dayanarak aşağıdaki sonuçlar çıkarılmış ve tartışılmıştır.

Zihinsel düşünme becerilerinin geliştirilmesinin, bilgilerin alınmasında, işlenmesinde ve yeni bilgilerin üretilmesinde etkili olduğu göz önüne alınırsa; öğrencilerde yaratıcı düşünme, analitik düşünme, eleştirel düşünme ve problem çözme becerisi gibi üst düzey zihinsel süreçleri harekete geçirecek yazılı materyaller tercih edilmesi gerektiği sonucu çıkarılabilir(Arıkan ve Kırındı, 2020). Aynı zamanda kullanılacak yazılı materyaller, bilgiye doğru kaynaklardan ulaşabilen, onu işleyerek karşıllaştığı yeni durumlara bu bilgileri uyarlayabilen ve bazı durumlarda genellemeler yapabilen öğrencilerin yetiştirilmesinde önemlidir.

Çalışmanın analiz sonuçları, incelenen beceri temelli 180 sorunun genel olarak Bloom taksonomisinin bilişsel süreç boyutu bakımından en fazla anlama $(\% 75,5)$ basamağına ait olduğunu göstermektedir. Bu durum analizi yapılan soruların yeniden yapılandırılmış Bloom 
taksonomisindeki dağılımının homojen olmadığını göstermektedir. Ayrıca soruların ezber gerektiren bir başka deyişle alt düzey zihinsel süreçleri harekete geçirmeye yönelik olduğunu söylemek mümkündür.

Beceri temelli test soruları taksonominin bilgi birikimi boyutu bakımından incelendiğinde ise beşinci ve yedinci sınıf kademesindeki soruların en fazla kavramlar bilgisi $(\% 88,33)$ seviyesine ve altıncı sınıf kademesindeki soruların en fazla olgular bilgisi (\%50) seviyesine ait sorular olduğu tespit edilmiştir. Bu oranlar yayımlanan 180 adet beceri temelli sorunun yapılandırmacı yaklaşımın, Fen Bilimleri öğretim programının ve yakın zamanda duyurulan MEB Eğitim 2023 Eğitim Vizyonu ile açılanan ölçme değerlendirme hedefleriyle örtüşmesi için geliştirilmesi gerektiğini göstermektedir (MEB, 2018). Beceri temelli sorular adından da anlaşılacağı gibi öğrencilere bazı becerileri kazandırmaları beklenen sorulardır. Fakat soruların analiz sonuçları incelendiğinde üst düzey düşünme becerilerine hitap etmesi gerekirken, öğrencilerin değerlendirilmesinde kavramları tanıma, sembolleri söyleme ve farklı kavramlar arasında ilişkiler kurabilme gibi becerilere hitap ettiği söylenebilir. Alt düzey düşünme becerilerinin ön planda olduğu beceri temelli testlerin öğrencilerin etkin bir biçimde üst düzey düşünme becerilerini kullanmalarına yönelik olmadığı ve bunun sonucunda da yaratıcılığı zedeleyen, öğrencileri ezbere yönelten testler olduğu söylenebilir. $\mathrm{Bu}$ yüzden öğretmenler ve soru hazırlayan uzmanlar soruları hazırlarken Bloom taksonomisini göz önünde bulundurmalıdırlar. Çünkü soruların üst düzey düşünme becerilerine hitap etmesi öğrencileri sınavlar dışında ve günlük hayatlarında yaratıcı düşünmelerini sağlar (Zorluoğlu, Olgun ve Kızılaslan, 2020). Aynı şekilde üst düzey düşünme becerileri öğrencilerin fen bilimlerini ve fen bilimlerinin doğasını daha iyi anlayıp yorumlamalarını sağlayabilir (Ataş ve Güneş, 2020).

Ayrıca elde edilen bulgular Ayvacı ve Türkdoğan (2010), Tanık ve Saraçoğlu (2011), Celep ve Bacanak (2013), Akçay, Akçay ve Kahramanoğlu (2017), Güven ve Aydın (2017) ve Yolcu (2019) tarafindan yapılan araştırma sonuçlarıyla paralellik göstermektedir. Ayvacı ve Türkdoğan (2010) Fen Bilimleri yazılı sorularını yeniden yapılandırılmış Bloom taksonomisine göre analiz ettikleri çalışmalarında incelenen soruların en fazla $(\% 38,4)$ hatırlama ve en az $(\% 0,5)$ yeniden oluşturma (yaratma) basamağında olduğunu tespit etmişlerdir. Aynı çalışmada incelenen 100 sorunun genel olarak kavramsal ve olgusal bilgi seviyesinde olduğunu ifade etmişlerdir. Yine Güven ve Aydın (2017) tarafindan yapılan araştırmada yeniden yapılandırılmış Bloom taksonomisine göre Fen Bilimleri dersi öğretim programı sorularını analiz ettikleri çalışmalarında 185 sorunun en fazla anlama (\%40) ve en az değerlendirme $(1,62)$ ve yaratma basamağında oldukları tespit edilmiştir. Bununla birlikte aynı 
çalışmada incelenen 185 sorunun \%70,81'inin alt düzey, \%29,19'unun ise üst düzey bilişsel süreç basamaklarını ölçtüğü tespiti de sunulmuştur. Tanık ve Saraçoğlu (2010) tarafindan yapılan bir başka çalışmada ise Fen Bilimleri dersine ait yazılı soruları incelenmiş ve öğretmenlerin öğrencilere sorduğu soruların \%51,6’ sının hatırlama basamağında olduğu tespit edilmiş ve aynı zamanda öğretmenlerin öğrencilere genelde ezbere dayalı sorular sordukları çıkarımı yapılmıştır. Bu sonuçlar çalışmamızın sonuçlarıyla paralellik göstermektedir.

Akçay, Akçay ve Kahramanoğlu (2017) tarafından ortaokul fen bilimleri ders kitapları değerlendirilmiş ve fen bilimleri dersi programlarından 1926 yılı programının üst düzey becerileri ölçtüğü buna karşın 2004 ve 2013 programının alt düzey becerileri ölçtüğü sonucuna varılmıştır. Yolcu (2019) ilkokul öğretim programı 3 ve 4. sınıf fen bilimleri dersi kazanımlarının revize edilmiş Bloom taksonomisine göre değerlendirilmesi adlı çalışmasında, \%72 kavramsal bilgi ve \%43 anlama basamağına hitap eden kazanımlara yer verildiği sonucuna ulaşmıştır. Beceri temelli testler de yazılı birer materyal sınıfına girmektedir. MEB kaynaklarına sıkı sıkıya bağlı olduğumuz göz önüne alınırsa yazılı materyalleri hazırlarken Bloom taksonomisinin iyi değerlendirmek ve gerek kazanımları gerekse de ders kitaplarını hazırlarken Bloom taksonomisi göz önünde bulundurulmalıdır. Üstelik yukarıdaki çalışmalar dikkate alındığında yıllar ilerledikçe teknolojinin de ilerlemesiyle daha çok üst düzey becerilere hitap eden eğitim materyallerin tercih edilmesi gerekirken, bunun aksine alt düzey becerilere hitap eden materyaller ortaya konulduğu görülmektedir (Ataş ve Güneş, 2020; Karamustafaoğlu, 2006).

Celep ve Bacanak (2013) yüksek lisans yapan öğretmenlerin bilimsel süreç becerileri kazandırılması hakkındaki görüşlerinin incelendiği çalışmanın sonuçlarına göre, öğretmenlerin bilimsel süreç becerilerini lisans eğitimi süresince en fazla laboratuvar derslerinde kazandıkları sonucu kaydedilmiştir. Aynı çalışmada bilimsel süreç becerilerinin; yansıtıcı düşünme, soyut düşünme, analitik düşünme, bilimsel düşünmeyi geliştirdiği sonucuna ulaşılmıştır. Bu sonuçlar ile paralellik gösteren çalışmamızda beceri temelli soruların üst düzey becerileri ölçmesi gerekirken aslında daha çok alt düzey becerileri ölçtüğü sonucuna varılabilir. Beceri temelli sorularda olduğu gibi düşük seviyedeki becerileri ölçen sorular ile öğrencilerin değerlendirilmeleri onların Fen Bilimleri dersine karşı ilgiyi ve merakı azaltmanın yanında öğrencilerin sorgulayıcı yapılarını baskılayabilir.

İncelenen soruların bütün sınıf seviyelerinde üst bilişsel bilgi ve yaratma (yeniden oluşturma) düzeyindeki soruların \%0 gibi bir değerde kalmış olması hiç rastlanamamış olması Fen Bilimleri dersinin hedefleri açısından çok düşük bir değerdir. Bu konunun özellikle 
üzerinde durulması gerekir. Çünkü bilim toplumu olduğumuz ve bilgiye ulaşmanın kolay olduğu şu zamanlarda öğretmenler bilgiyi vermeyi değil doğru bilgiye nasıl ulaşılabileceğine yönelik sorular sormalıdırlar. Aynı şekilde sorulan sorular, bilgileri sadece bilmeyi değil bu bilgilerin yeni durumlarda nasıl kullanılması gerektiğini irdeleyen sorular olmalıdır. Yenilenen öğretim programının ölçme ve değerlendirme hedeflerine bakıldığında ölçme ve değerlendirme çalışmalarının öğrencileri bir bütün olarak değerlendirilmesi ve hiçbir bireyin birbiriyle aynı olamayacağı için ölçme değerlendirme çalışmalarının da her bireye hitap edecek düzeyde yapılması gerektiği vurgulanmıştır (MEB, 2018).

Bilişsel gelişim; bebeklikten erişkinliğe kadar bireyin yakın çevresini, yaşadığı dünyayı anlama, düşünme yollarının daha karmaşık ve etkili hale gelmesi sürecidir (Sönmez, 2019). Jean Piaget' in Bilişsel Gelişim Kuramı' nda açıklandığı üzere somut işlemler dönemi 7-11 yaş aralığındaki çocukları kapsar. Aynı şekilde soyut işlemler dönemi de 11-15 yaş aralığını kapsamaktadır. Bu durumda ilkokul ve ortaokul öğrencilerinin zihinsel gelişim bakımından somut ve soyut işlemler döneminde bulunduklarını söylemek mümkündür (Daşçı ve Yaman, 2014). Araştırmanın temelini oluşturan beceri temelli soruların yöneltileceği öğrenci grubu bu bağlamda iki gruba ayrılmaktadır. Beşinci sınıflar yaş grubu itibariyle genel olarak somut dönemde bulunurken altıncı ve sekizinci sınıflar da genel olarak soyut işlemler döneminde bulunurlar. Buna göre soru hazırlayacak uzman kişilerin bu durumlara da dikkat etmeleri gereklidir.

Somut işlemler dönemde çocuklar adından da anlaşıldığı üzere sınıflama, sıralama, gruplandırma gibi işlemleri yapmakla birlikte sayı, mesafe, mekân gibi kavramlarını öğrenebilir. Soyut işlemler döneminde ise tümevarım ve tümdengelim gibi üst düzey zihinsel düşünme becerilerini kazanabilir. Beceri temelli sorular Piaget' in Bilişsel Gelişim Kuramı açısından incelendiğinde beşinci ve altıncı sınıf seviyesindeki soruların bu kurama uygun hazırlandığı fakat soyut dönemde bulunan sekizinci sınıf öğrencilerine yönelik olmadı̆̆ söylenebilir. Bu durumda sekizinci sınıf öğrencilerine yönelik soruların taksonomi tablosuna bakılırsa çözümleme $(\% 1,7)$, değerlendirme $(\% 1,7)$ ve yaratma $(\% 0)$ basamaklarına yönelik soruların yetersiz olduğu söylenebilir. Aynı şekilde beşinci ve altıncı sınıf seviyesindeki soruların genel olarak hatırlama ve anlama basamağında yoğunlaştığı görülmekte fakat bu kademedeki öğrenciler uygulama ve çözümleme basamağındaki soruları da çözebileceklerinden dolayı bu konuda da bazı düzenlemelerin yapılması gerekmektedir. 


\section{Öneriler}

Yapılan bu çalışmanın verilerinin analizi sonucunda aşağıdaki öneriler oluşturulmuş olup söz konusu önerilerin MEB başta olmak üzere diğer tüm paydaşlara yol göstereceği düşünülmektedir.

1- Öğretim sürecinde MEB' in yayımladığı yazılı materyallere (ders kitapları, beceri temelli sorular vb.) sıkı sıkıya bağlı olan ülkemizde öğretmenlerin çeşitli farkındalıklar yaratmaları, soru sorma ve soru analiz etme becerilerini geliştirmeleriyle ilgili hizmet öncesi ve hizmet içi eğitimlerin niteliği artırılmalıdır. $\mathrm{Bu}$ eğitimler, teorik ve uygulamalı olarak yapılmalıdır.

2- Öğretmenler Bloom taksonomisini ve öğretim programında belirtilen kazanımları iyi analiz edip taksonominin üst düzey düşünme becerilerini içeren sorular sunmalıdırlar. Ayrıca burada öncelikle öğrencilere verilecek eğitimin niteliği ve ders işleyişi önemlidir. Çünkü üst düzey becerileri içeren sorular sorabilmek için üst düzey becerilerin öğrencilere kazandırılmış olması gerekir.

3- Alanında uzman kişilerin ve öğretmenlerin katılımıyla Bloom taksonomisine uygun soru havuzları oluşturularak, MEB veya MEB EBA portalında paylaşımlar yapılabilir.

\section{Makalenin Bilimdeki Konumu}

\section{Matematik ve Fen Bilimleri Eğitimi Bölümü/Fen Bilgisi Eğitimi}

\section{Makalenin Bilimdeki Özgünlüğü}

Yeniden yapılandırılmış Bloom Taksonomisi literatürde sıkça yer verilen bir konudur. Fen Bilimleri dersi kapsamında hazırlanan soruların Bloom Taksonomisine uygunluğu ile ilgili çalışmaların sınırlı olduğu söylenebilir. Bu çalışmalar incelendiğinde, yıllar ilerledikçe bilim ve teknolojinin gelişmesiyle öğrencilere yöneltilen soruların ait olduğu basamakların genel olarak birbiriyle paralel olduğu yani alt düzey zihinsel becerilere hitap ettiği saptanmıştır. Günümüzde bu eksikliğin giderilmesi için MEB tarafından Beceri Temelli Testler yayımlanmış ve bu soruların öğrencilere mutlaka çözdürülmesi gerektiği uyarıları yapılmıştır. Buradan yola çıkarak üzerinde uzun zaman durulan ve bütün paydaşlar tarafından dikkate alınan Beceri Temelli olarak adlandırılan soruların hangi zihinsel sürece hitap ettiği ortaya çıkarılmak için bu çalışma ortaya konulmuştur. 


\section{Kaynakça}

Akbulut, T. (1999). Illköğretim okullarında görevli ögretmenlerin soru sorma becerilerinin bazı değişkenler açısından incelenmesi. Yayımlanmamış yüksek lisans tezi, Sosyal Bilimler Enstitüsü, Çukurova Üniversitesi, Adana.

Akçay, B., Akçay, H. ve Kahramanoğlu, E. (2017). Ortaokul fen bilimleri ders kitaplarının Bloom taksonomisine göre incelenmesi. Uludağ Üniversitesi Ĕ̆itim Fakültesi Dergisi, 30(2), 521-549.

Akyol, H., Yıldırım, K., Seyit, Ateş ve Çetinkaya, Ç. (2013). Anlamaya yönelik nasıl sorular soruyoruz? Mersin Üniversitesi Ĕgitim Fakültesi Dergisi, 9(1), 41-56.

Anderson, L.W. (Ed.), Krathwohl, D.R. (Ed.), Airasian, P.W., Cruikshank, K. A., Mayer, R.E., Pintrich, P. R., Raths, J. \& Wittrock, M. C. (2001). A taxonomy for learning, teaching, and assessing: A revision of Bloom's taxonomy of educational objectives. New York: Longman.

Anderson, L. W. (2005). Objectives, evaluation, and the improvement of education. Studies in Educational Evaluation, 31, 102-113.

Arıkan, O., ve Kırındı, T. (2020). OKS, SBS, TEOG Fen Bilimleri Testi Sorularının Bilimsel Süreç Becerileri ve Eleştirel Düşünme Becerilerine Göre İncelenmesi. Turkish Journal of Primary Education, 5(2), 155-170.

Ataş, E \& Güneş, P. (2020). Altıncı sınıf fen bilimleri dersi sınav sorularının yeniden yapılandırılmış Bloom taksonomisine göre değerlendirilmesi. Bolu Abant İzzet Baysal Üniversitesi Eğitim Fakültesi Dergisi, 20(2), 1066-1078.

Aydemir, Y. ve Çiftçi, Ö. (2008). Edebiyat öğretmeni adaylarının soru sorma becerileri üzerine bir araştırma (Gazi Üniversitesi Eğitim Fakültesi Örneği). Yüzüncü Yll Üniversitesi Ĕ̌itim Fakültesi Dergisi, 5(2), 103-115.

Ayvacı, H. Ş. ve Türkdoğan, A. (2010). Yeniden yapılandırılan Bloom taksonomisine göre fen ve teknoloji dersi yazılı sorularının incelenmesi. Türk Fen Eğitimi Dergisi, 7(1), 13-25.

Başkale, H. (2016). Nitel araştırmalarda geçerlik, güvenirlik ve örneklem büyüklügünün belirlenmesi. Dokuz Eylül Üniversitesi Hemşirelik Fakültesi Elektronik Dergisi, 9(1), 2328.

Bircan, E. (2012). Türkçe öğretmeni adaylarının hazırladığı soruların yeniden yapılandırılan bloom taksonomisine göre değerlendirilmesi. Kastamonu Eğitim Dergisi, 20(3), 965982. 
Bloom, B. S. (1956). Taxonomy of educational objectives: Cognitive and affective domains. New York: David McKay.

Bowen, G. A. (2009). Document analysis as a qualitative research method. Qualitative Research Journal, 9(2), 27.

Büyükalan, Filiz, S. (2002). Soru-cevap yöntemine ilişkin ögrretimin öğretmenlerin soru sorma düzeyi ve tekniklerine etkisi. Yayımlanmamış doktora tezi, Eğitim Bilimleri Enstitüsü, Ankara Üniversitesi, Ankara.

Cangüven, H. D., Oya, Ö. Z., Binzet, G., ve Gülşen, Avc1 (2017). Milli Eğitim Bakanlığı 2017 Fen Bilimleri Taslak Programının Yenilenmiş Bloom Taksonomisine Göre İncelenmesi. International Journal of Eurasian Education and Culture, 2(2), 62-80.

Celep, A. ve Bacanak, A. (2013). Yüksek lisans yapan öğretmenlerin bilimsel süreç becerileri ve kazandırılması hakkındaki görüşleri. Journal of Turkish Science Education, 10(1), 5678.

Cumhur, F., Çavdar, O. ve Polat, S. (2018). Matematik ve fen bilimleri öğretmeni adaylarının Bloom taksonomisine göre oluşturdukları soruların değerlendirilmesi. Journal of Social and Humanities Sciences Research, 5(28), 3243-3252.

Çalışkan, H. (2011). Öğretmenlerin hazırladığı sosyal bilgiler dersi sınav sorularının değerlendirilmesi. Eğitim ve Bilim, 36(160), 120-132.

Çavuş, R., Balçın, M. D. ve Yılmaz, M. M. (2018). Bilim fuarı etkinliklerinin ortaokul öğrencilerinin fen ve problem çözme becerilerine yönelik algılarına etkisi. Inönü Üniversitesi Eğitim Bilimleri Enstitüsü Dergisi, 5(10), 1-17.

Çepni, S. ve Azar, A. (1998). Lise fizik sınavlarında sorulan soruların analizi. III. Ulusal Fen Bilimleri Eğitimi Kongresi, Karadeniz Teknik Üniversitesi, Trabzon.

Çepni, S., Ayvacı, H. Ş. ve Keleş, E. (2001). Okullarda ve lise giriş sınavlarında sorulan fen bilgisi sorularının Bloom taksonomisine göre karşılaştııılması. Fen Bilimleri Eğitimi Sempozyumu, ss. 7-8.

Çepni, S. (2018). Araştırma ve proje çalışmalarına giriş. Trabzon: Celepler Yayıncılık.

Çınar, D. ve Aslan, İ. (2013). İlköğretim fen eğitiminde probleme dayalı öğrenme yaklaşımının üst düzey düşünme becerilerine etkisi. Eğitim Bilimleri Araştırmaları Dergisi, 3(2), 2134.

Daşc1, A. D. ve Yaman, S. (2014). Fen ve teknoloji dersinde öğrencilerin zihinsel risk alma becerilerinin Piaget'in bilişsel gelişim dönemlerine ve eğitim kademelerine göre incelenmesi. Kuramsal Eğitimbilim Dergisi, 7(3), 271-285. 
Dindar, H. ve Demir, M. (2006). Beşinci sınıf öğretmenlerinin fen bilgisi dersi sınav sorularının Bloom taksonomisine göre değerlendirilmesi. Gazi Üniversitesi Gazi Ĕ̆itim Fakültesi Dergisi, 26(3), 87-96.

Eke, C. (2015). Dalgalar ünitesindeki kazanımların yenilenmiş bloom taksonomisine göre incelenmesi. Ĕgitim ve Öğretim Araştırmaları Dergisi, 4(2), 345-353.

Eroğlu, D. ve Kuzu, T. S. (2014). Türkçe ders kitaplarındaki dilbilgisi kazanımlarının ve sorularının yenilenmiş Bloom taksonomisine göre değerlendirilmesi. Başkent University Journal of Education, 1(1), 72-80.

Gökulu, A. (2015). Fen ve teknoloji öğretmenlerinin yazılı sınav soruları ile TEOG sınavlarında sorulan fen ve teknoloji sorularının yenilenmiş Bloom taksonomisine göre incelenmesi. Route Educational and Social Science Journal, 2(2), 434-446.

Gül, D. (2006). Somut işlem döneminde olan 8-9 yaş çocuklart ile soyut işlem döneminde olan 12-13 yaş çocukların görsel bellek farklılıklarının incelenmesi. Yayımlanmamış yüksek lisans tezi, Sosyal Bilimler Enstitüsü, Maltepe Üniversitesi, İstanbul.

Güleryüz, H. ve Erdoğan, İ. (2018). Ortaokul fen bilimleri dersi sınav sorularının Bloom’un bilişsel alan taksonomisine göre değerlendirilmesi: Muş İli Örneği. Anemon Muş Alparslan Üniversitesi Sosyal Bilimler Dergisi, 6(1), 43-49.

Gündüz, Y. (2009). İlköğretim 6, 7 ve 8. sınıf fen ve teknoloji sorularının ölçme araçlarına ve Bloom’un bilişsel alan taksonomisine göre analizi. Van Yüzüncü Yıl Üniversitesi Ĕgitim Fakültesi Dergisi, 6(2), 150-165.

Güven, Ç. ve Aydın, A. (2017). 8. sınıf fen ve teknoloji dersi öğretim programından bulunan soruların yenilenmiş Bloom taksonomisinin bilişsel süreç boyutuna göre incelenmesi. Türkiye Kimya Derneği Dergisi, Kısım C: Kimya Eğitimi, 2(1), 87-104.

Karaman, M. ve Bindak, R. (2017). İlköğretim matematik öğretmenlerinin sınav soruları ile TEOG matematik sorularının yenilenmiş Bloom taksonomisine göre analizi. Current Research in Education, 3(2), 51-65.

Karamustafaoğlu, O. (2006). Fen ve teknoloji öğretmenlerinin öğretim materyallerini kullanma düzeyleri: Amasya ili örneği. Atatürk Üniversitesi Bayburt Eğitim Fakültesi Dergisi, 1(1), 90-101.

Koray, Ö., Altunçekiç, A. ve Yaman, S. (2005). Fen bilgisi öğretmen adaylarının soru sorma becerilerinin Bloom taksonomisine göre değerlendirilmesi. Pamukkale Üniversitesi Ĕ̌itim Fakültesi Dergisi, 17(17), 33-39. 
Koray, Ö., Yaman, S., (2002). Fen bilgisi öğretmenlerinin soru sorma becerilerinin Bloom taksonomisine göre değerlendirilmesi. Kastamonu Ĕ̆itim Dergisi, 10(2), 317-324.

Köğce, D. ve Baki, A. (2009). Matematik öğretmenlerinin yazılı sınav soruları ile ÖSS sinavlarında sorulan matematik sorularının Bloom taksonomisine göre karşılaştırılması. Pamukkale Üniversitesi Eğitim Fakültesi Dergisi, 26(26), 70-80.

Krathwohl, D. W. (2002). A Revision of Bloom's taxonomy: an overview. Theory into Practice. 41, 4, 212-218.

Mandacı-Şahin, S. (2007). 8. Sınıf öğrencilerinin matematik gücünün belirlenmesi. Yayımlanmamış doktora tezi. Fen Bilimleri Enstitüsü, Karadeniz Teknik Üniversitesi Trabzon.

Milli Eğitim Bakanlığı (2018). Fen bilimleri dersi öğretim programı (ilkokul ve ortaokul 3, 4, 5, 6, 7 ve 8. sinıflar) ögretim programı. Ankara: Devlet Kitapları Basım Evi.

Milli Eğitim Bakanlığı (2018). Eğitim 2023 Vizyonu. http://2023vizyonu.meb.gov.tr/ adresinden 10.10.2019 tarihinde erişildi.

Miles, M. \& Huberman, A. M. (1994). Qualitative data analysis. Newbury: CA SAGE.

Özcan, S. ve Akcan, K. (2010). Fen Bilgisi öğretmen adaylarının hazırladığı soruların içerik ve Bloom taksonomisine uygunluk yönünden incelenmesi. Kastamonu Ĕ̆itim Dergisi, 18(1), 323-330.

Sönmez, V. (2019). Zekâ ve bilişsel gelişim. Eğitim bilimine giriş. (15. Baskı) içinde (114118). Ankara: Anı Yayınları.

Tanık, N., ve Saraçoğlu, S. (2011). Fen ve teknoloji dersi yazılı sorularının yenilenmiş Bloom taksonomisine göre incelenmesi. Tübav Bilim Dergisi, 4(4), 235-246

Turgut, M. F. ve Baykul, Y. (2010). Ĕ̆itimde ölçme değerlendirme. Ankara: Pegem Yayıncilık.

Tutkun, Ö. F. ve Okay, S. (2012). Bloom'un yenilenmiş taksonomisi üzerine genel bir bakış. Sakarya University Journal of Education, 1(3), 14-22.

Yaz, Ö. V., ve Kurnaz, M. A. (2013). 2013 Fen Bilimleri Öğretim Programının İncelenmesi. Uluslararası Türk Ĕgitim Bilimleri Dergisi, 2017(8), 173-184.

Yıldırım, A. ve Şimşek, H. (2018). Sosyal bilimlerde nitel araştırma yöntemleri. Ankara: Seçkin Yayınları.

Yolcu, H. H. (2019). İlkokul öğretim programı 3 ve 4. sınıf fen bilimleri dersi kazanımlarının revize edilmiş Bloom taksonomisi açısından analizi ve değerlendirilmesi. Elementary Education Online, 18(1), 253-262. 
YYÜ Eğitim Fakültesi Dergisi (YYU Journal of Education Faculty), 2021; 18(1) 219-248, http://efdergi.yyu.edu.tr,

Yurdabakan, İ. (2012). Bloom’un revize edilen taksonomisinin eğitimde ölçme ve değerlendirmeye etkileri. Gaziantep University Journal of Social Sciences, 11(2), 327348.

Zorluoğlu, S. L., Olgun, M. ve Kızılaslan, A. (2020). Fen bilimleri dersi ile ilgili yenilenmiş bloom taksonomisine yönelik Türkiye’de yapılan araştırmaların içerik analizi. Trakya Ĕgitim Dergisi, 10(1), 22-31. 


\section{Summary}

In literature, there are several studies focusing on examinations conducted in accordance with the re-structured taxonomy. According to Mandac1-Şahin (2007), though a constructive approach to teaching has been adopted in Turkey, analysis of the national and international exams demonstrates that we have not internalized this approach with respect to measurement and evaluation at all. In this respect, it could be stated that the student-centered education approach has not yet been internalized, and in order to overcome this problem, multiple-choice questions are suggested to be prepared in accordance to the constructive approach. Not all individuals can prepare multiple-choice questions to be used as a measurement tool. Preparing a question not only requires knowing how to raise others' curiosity and how to increase their willingness to learn but also necessitates putting forward various statements to test others’ knowledge (Akbulut, 1999). In their study, Köğce and Baki (2009) examined the exam questions prepared by mathematics teachers, and the researchers concluded that the questions generally measured low-level thinking skills. In another study, Gündüz (2009) examined Science and Technology questions and found that $64.65 \%$ of the questions tested knowledge and that 92,19\% of all were low-level questions. Moreover, Ayvac1 and Türkdoğan (2010) examined the questions prepared by Science and Technology teachers in accordance with the new taxonomy, and the researchers reported that 55\% of the questions tested remembering and knowledge. Karaman and Bindak (2017), in their study, found that $72,5 \%$ of the questions directed in TEOG (a multiple-choice national exam administered for the placement of secondary school students) were low level and 27,5\% of them were upper level. The researchers also revealed that $41,3 \%$ of the exam questions prepared by the teachers were at the steps of understanding and application. In another study, Güven and Aydın (2017) examined the questions within the scope of the curriculum of the secondary school $8^{\text {th }}$ grade course of Science and found that $48,72 \%$ of the questions belonged to the step of understanding. Yolcu (2019) investigated the outcomes of the elementary school $3^{\text {rd }}$ grade and $4^{\text {th }}$ grade course of Science in accordance with the revised taxonomy and reported that $43 \%$ of the outcomes addressed the step of understanding. In general, studies demonstrate that instead of questions which measure low-level intellectual skills, which only interrogate the knowledge and which are based on memorization, it is necessary to prepare questions which allow interpreting the knowledge, which help adapt current knowledge to new situations and which provide the opportunity to establish communication with different disciplines. 
As can be seen, the re-structured Bloom Taxonomy is a subject frequently mentioned in related literature. The number of studies conducted in relation to the course of Science as well as the curriculum of this course is quite limited. In addition, when the current studies are examined, it is seen that in line with the development of science and technology, the questions directed to students generally addressed parallel steps; in other words, the questions addressed low-level intellectual skills. Today, for the purpose of overcoming this deficiency, Skill-Based Tests have been published by MoNE, and the Ministry warned the authorities to have the students answer these questions. These questions named Skill-Based have long been taken into considered by all the stakeholders, and in this respect, the purpose of the present study was to reveal which intellectual process these skill-based questions addressed. In addition, the study further aimed to raise awareness of the importance of upper-level thinking skills.

\section{Method}

\section{Research Design}

In the study, the document analysis method, one of qualitative research methods, was applied. Document analysis refers to the examination of visual materials which include information about the phenomenon or phenomena to be investigated (Yıldırım and Şimşek, 2018). In another saying, document analysis is the procedure of gathering, grouping and examining systematically the written materials related to the study to be conducted (Çepni, 2018).

\section{Data Source}

The research data included the tests made up of skill-based multiple-choice questions published on the official website of MoNE regarding the course of Science on 7 October, 2019. These skill-based questions addressed secondary school $5^{\text {th }}, 6^{\text {th }}$ and $7^{\text {th }}$ grades and covered the first lesson units of each grade.

\section{Data Collection}

After the research purposes and the main problems were determined, the skill-based questions taken from the official website of MoNE were transformed into a written material in three groups for each class grade. In addition, Bloom taxonomy, which constituted the basis of the study, was formed in line with the related literature and presented in tables.

\section{Data Analysis}

The research data were analyzed considering the main problem of the study. While analysing the questions, the cognitive process and knowledge dimensions of the re-structured Bloom Taxonomy were taken into account. In order to find which step of the taxonomy the 
questions belonged to, first, the sentence structures of the main points of the questions were first examined. A basic sentence is constructed with a noun and a verb. For the analysis of the questions, they were divided into two groups: nouns and verbs. In this way, the nouns used in the question allowed finding the knowledge dimension, and the verbs allowed revealing the cognitive process dimension. In this analysis process, while placing the questions with horizontal and vertical dimensions in the taxonomy table, the steps that the questions belonged to were determined considering the verbs and nouns found in the taxonomy table.

\section{Findings}

When the skill-based multiple-choice questions were examined with respect to the knowledge dimension, it was seen that the questions for the $5^{\text {th }}$ and $7^{\text {th }}$ grades were those mostly related to knowledge of concepts $(88,33 \%)$ and that the questions for the $6^{\text {th }}$ grade were mostly related to knowledge of phenomena (50\%). These percentages show that these 180 skill-based questions should be developed parallel to the constructive approach, the Science curriculum and the measurement goals recently announced with the MoNE 2023 Education Vision (MoNE, 2018). As can be understood from its name, skill-based questions are those expected to help students acquire certain skills. However, when the analysis results of the questions were examined, it was seen that they addressed such skills as knowing concepts, stating symbols and establishing relationships between different concepts though the questions should actually have addressed upper-level thinking skills. It could be stated that skill-based tests, in which lowlevel thinking skills are prominent, do not aim to have students make effective use of upperlevel thinking skills and that these skill-based tests thus damage creativity and lead students to memorization. Therefore, while preparing questions, teachers and experts should take Bloom taxonomy into consideration because questions addressing upper-level thinking skills allow students to think creatively not only during exams but also in their daily lives. Similarly, upperlevel thinking skills could help students better understand and interpret science and the nature of science. 